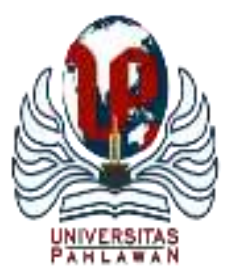

Edukatif : Jurnal Ilmu Pendidikan Volume 4 Nomor 1 Tahun 2022 Halm 887 - 897

EDUKATIF: JURNAL ILMU PENDIDIKAN

Research \& Learning in Education

https://edukatif.org/index.php/edukatif/index

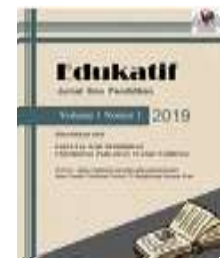

\title{
Information and Service Challenges in the 5.0 Industrial Revolution on Student Satisfaction: Empirical Analysis in the Department of Electronics
}

\author{
Muhammad Husin ${ }^{1 凶}$, Ambiyar², Nurhasan Syah $^{3}$ \\ Universitas Negeri Padang, Indonesia ${ }^{1,2,3}$ \\ E-mail : $\underline{\text { muhammadhusin55@unp.ac.id }}{ }^{1}, \underline{\text { ambiyar@ ft.unp.ac.id }}^{2}, \underline{\text { nurhasan@ } @ \text { ft.unp.ac.id }}^{3}$
}

\begin{abstract}
Abstrak
Revolusi industry 5.0 mempengaruhi seluruh pendidikan yang ada diperguruan tinggi diseluruh dunia. Penyebaran virus COVID-19 berdampak kepada sistem pendidikan. Perubahan situasi ini mempengaruhi kepuasan mahasiswa dalam menempuh pendidikan. Perguruan tinggi harus meningkatkan kualitas informasi dan kualitas pelayanan untuk mencapai kepuasan pada diri mahasiswa dan dapat bersaing menuju revolusi industry 5.0. Penelitian ini bertujuan untuk menganalisis pengaruh kualitas informasi dan kualitas pelayanan terhadap kepuasan mahasiswa. Penelitian ini termasuk penelitian korelasional. Subyek penelitian adalah mahasiswa Pendidikan Teknik Informatika yang berjumlah 100 orang. Teknik analisis data yang digunakan adalah uji regresi. Hasil penelitian menunjukkan bahwa (1) kualitas informasi berpengaruh positif dan signifikan terhadap kepuasan mahasiswa (2) kualitas pelayanan berpengaruh positif dan signifikan terhadap kepuasan mahasiswa (3) kualitas informasi dan kualitas pelayanan secara bersama-sama berpengaruh positif dan signifikan terhadap kepuasan mahasiswa. Temuan ini memberikan persepsi untuk meningkatkan persaingan menuju revolusi industry 5.0 dan kepuasan mahasiswa perguruan tinggi harus memperbaharui kualiatas informasi dan kualitas pelayanannya.
\end{abstract}

Kata Kunci: Kualitas Informasi, Kualitas Pelayanan, Kepuasan Mahasiswa, Revolusi Industri 5.0

\begin{abstract}
The industrial revolution 5.0 has had an impact on all education in universities. The spread of the COVID-19 virus has an impact on the education system. These changes affect student satisfaction in taking education. Universities must improve the quality of information and service quality to achieve student satisfaction. This study aims to analyze the effect of information quality and service quality on student satisfaction. This research includes correlational research. The subjects of this study were 100 students of Informatics Engineering Education. The data analysis technique is regression test. The results showed that (1) the quality of information had a positive and significant effect on student satisfaction (2) the quality of service had a positive and significant effect on student satisfaction (3) the quality of information and the quality of service together had a positive and significant effect on student satisfaction. These findings provide a perception to increase competition towards the industrial revolution 5.0 and the satisfaction of college students must update the quality of information and service quality.
\end{abstract}

Keywords: Information Quality, Service Quality, Student Satisfaction, Industrial Revolution 5.0

Copyright (c) 2022 Muhammad Husin, Ambiyar, Nurhasan Syah

$\triangle$ Corresponding author:

Email : muhammadhusin55@unp.ac.id

DOI : https://doi.org/10.31004/edukatif.v4i1.1956

ISSN 2656-8063 (Media Cetak)

ISSN 2656-8071 (Media Online)

Edukatif : Jurnal Ilmu Pendidikan Vol 4 No 1 Tahun 2022 p-ISSN 2656-8063 e-ISSN 2656-8071 


\section{INTRODUCTION}

The development of the industrial revolution 5.0 has affected the world of education (Hidayat et al., 2021; Anwar, 2021). The way of thinking about education has also changed due to the industrial revolution 5.0 (George \& George, 2020; Ellitan, 2020; Husin et al., 2021). Character education, morals, and exemplary are the most important parts that must exist in the world of education in the era of the industrial revolution 5.0 (Rosa \& Mujiarto, 2020; Malau, 2021). In industrial revolution 5.0, the knowledge possessed by students was replaced by technology (Shaddiq et al., 2021), and soft skills (Hidayat et al., 2021; Suan CHIN, 2021), as well as hard skills (Balrwein \& Rahman, 2020) technology, cannot be replaced. In the industrial era, 4.0 (Farida et al., 2020; Rymarczyk, 2021) emphasis lies on the digital revolution (Rindfleisch, 2020) in the form of cyberphysical while the industrial revolution 5.0 made humans the center (Arıc1 \& Kitapci, 2021) by utilizing digital technology as a tool in managing all life in various fields. Human to machine or vice versa is an existing emphasis. Industry revolution 5.0 (Longo et al., 2020; Rachmadtullah et al., 2020) not only the relationship between machine to machine and robotics (Anshari, 2020).

The Indonesian government must continue to improve the development of digital infrastructure (Purbasari et al., 2020) by making various policies and regulations (Adawiyah et al., 2021) to grow and develop the telecommunications industry to compete with other countries in welcoming the 5.0 industrial revolution. The turning of the education system to digital devices is also the impact of the spread of the COVID-19 virus that has hit the whole world (Chen et al., 2020; B, 2020; Joseph Paschal \& Mkulu, 2020). The learning system is all converted into a digital form to prevent the spread of the COVID-19 virus (Crawford et al., 2020; Mhlanga \& Moloi, 2020; Maity et al., 2021). Colleges/universities rearrange their learning systems which are usually done conventionally and must be done online (Shukla et al., 2020; Silalahi \& Hutauruk, 2020; Bestiantono et al., 2020). With the development of the industrial revolution 5.0 (Aprilisa, 2020) and the impact of the COVID-19 virus (Toquero, 2020) Bostan et al., 2020) every college/university must continue to provide learning to students so that they can compete later. Higher education is a sector that produces human resources (Saravanakumar, 2020; Hasbullah et al., 2020) quality, and to achieve this, universities must improve the ability of students to meet the demands of people's lives (Kandiko Howson \& Lall, 2020).

Information Technology (Samimi, 2020; Alam, 2020) is one of the means to improve the quality of human resources (Jaya, 2020; Dewi \& Hoesada, 2020) in the face of industrial revolution 5.0 (Ellitan, 2020) and limited space for movement due to the spread of the COVID-19 virus (Freeman \& Eykelbosh, 2020; Bhagat et al., 2020). Information technology is currently developing very rapidly (Suresh et al., 2004; Asuquo et al., 2020). Improving services from the various features provided can increase the activity of an organization (Kuzieva, 2019) Shukshina et al., 2020) is a part of information technology (Sofyani et al., 2020). Universities are currently trying to improve the quality of their information to students to meet the demands of the 5.0 industrial revolution (Yosintha, 2020). The focus of this information technology is to provide information systems in various aspects of activities in the industrial world, in which developments continue to rise rapidly (Oztemel \& Gursev, 2020; Dwivedi et al., 2020). Accuracy, relevance, and timeliness are the main keys that must be provided in information technology (Al-Okaily et al., 2020) to improve the information system for students. Satisfaction(Kurdi et al., 2020) obtained by students in obtaining information is a form of the success of universities in implementing information systems (Abdurrahaman et al., 2020) in the form of service quality. Providing accurate service quality to students in gathering information that is currently developing can increase student satisfaction (Cahyono et al., 2020; Li et al., 2021). Student perception is a comprehensive assessment of the superiority of a service (Minh, 2020). The intense competition in welcoming the 5.0 industrial revolution must be anticipated by universities. Universities must improve and explore all aspects of education (Alshehri \& Cumming, 2020). Service quality (Demir et al., 
2020; Tešić, 2020) given is one method to provide satisfaction to (Mulyono et al., 2020) students and is one of the important factors in determining the success of higher education. Students must be able to feel satisfied. To achieve this, every university must be involved in a series of breakthrough activities to improve the quality of higher education services (Liu et al., 2020). Universities can succeed by identifying the factors that will affect services using information technology. The development of information has a great influence on a company in the business world (Akbar et al., 2020). All transactions can be done in real-time and recorded online so that they can be seen directly (Ekaso et al., 2020).

Service improvement (Locock et al., 2020) has been developed by a company and the quality of its service can be measured (Restuputri et al., 2020). With this information system, service performance can be measured and increase employee motivation. The information system in question will disseminate information that is likely to provide benefits to users by utilizing information technology in the classroom. Finally, it will improve the quality of service that will be received by students. The profile of a university will also increase because it provides satisfaction to students with quality information that is accurate, efficient, and timely as well as the best service. Identifying factors in information systems and service quality are the aim of this study. The results of the study can be used as a benchmark for universities to maximize service quality and be able to compete in the era of the industrial revolution 5.0.

\section{METHOD}

This research is included in correlational research based on problems because it aims to see the effect of information quality and service quality on student satisfaction (Y. Wang, 2021).

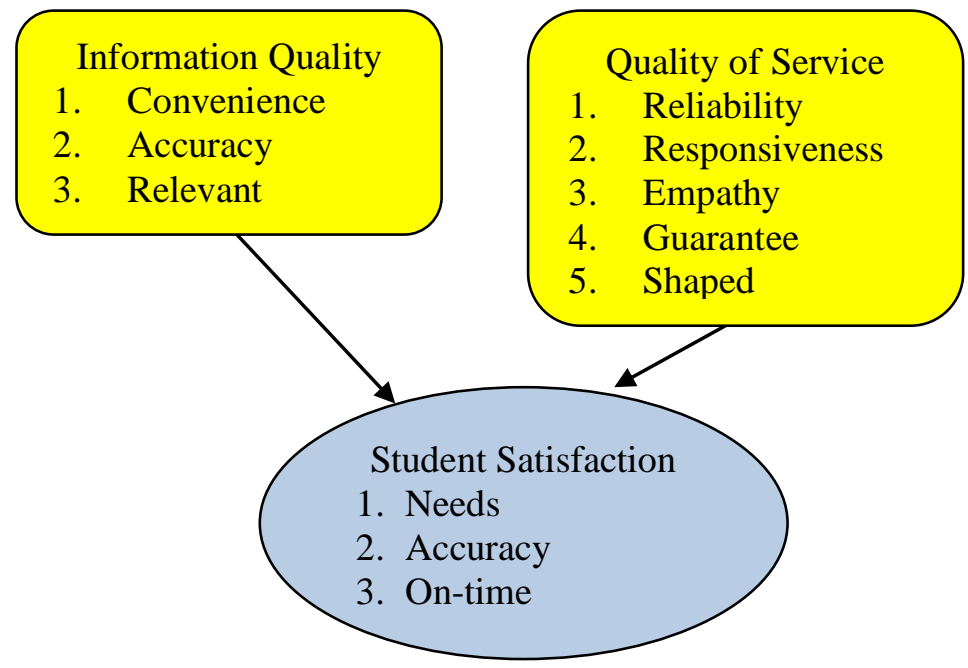

Figure1. Research Thinking Framework

The way researchers describe the variables to be studied with their parameters is a function of the operational definition (Table 1).

Table 1

Variable Operational Definition

\begin{tabular}{|c|c|c|c|c|}
\hline Variables & Definition & Dimension & Indicators & Scoring scale \\
\hline $\begin{array}{l}\text { Information } \\
\text { Quality (X1) }\end{array}$ & $\begin{array}{l}\text { Information can } \\
\text { meet the } \\
\text { requirements and } \\
\text { expectations of } \\
\text { those who need } \\
\text { information }\end{array}$ & 1. Convenience & $\begin{array}{l}\text { a. Easy to use } \\
\text { b. Clear instructions } \\
\text { c. How to work is easy to } \\
\text { understand } \\
\text { a. Accurate information } \\
\text { b. Provide a proper report } \\
\text { c. Trust me }\end{array}$ & Likert \\
\hline
\end{tabular}


890 Information and Service Challenges in the 5.0 Industrial Revolution on Student Satisfaction: Empirical Analysis in the Department of Electronics - Muhammad Husin, Ambiyar, Nurhasan Syah

DOI: https://doi.org/10.31004/edukatif.v4i1.1956

\begin{tabular}{|c|c|c|c|c|}
\hline Variables & Definition & Dimension & Indicators & Scoring scale \\
\hline & & 3. Relevant & $\begin{array}{l}\text { a. According to the needs } \\
\text { b. New information }\end{array}$ & \\
\hline $\begin{array}{l}\text { Quality of Service } \\
\text { (X2) }\end{array}$ & $\begin{array}{l}\text { Forms of service in } \\
\text { meeting the needs } \\
\text { and expectations of } \\
\text { users }\end{array}$ & $\begin{array}{l}\text { 1. Reliability } \\
\text { 2. Responsiveness }\end{array}$ & $\begin{array}{l}\text { a. Suitability } \\
\text { b. On-time } \\
\text { c. Well delivered } \\
\text { a. Quick response } \\
\text { b. Clear } \\
\text { c. Be careful } \\
\text { d. Respond to complaints } \\
\text { a. Solution } \\
\text { b. Polite } \\
\text { c. Provide security } \\
\text { a. Polite } \\
\text { b. Patience in serving } \\
\text { c. Concern } \\
\text { a. Convenience } \\
\text { b. Completeness }\end{array}$ & Likert \\
\hline $\begin{array}{l}\text { Student } \\
\text { Satisfaction (Y) }\end{array}$ & $\begin{array}{l}\text { Feeling } \\
\text { disappointed or } \\
\text { satisfied with } \\
\text { something }\end{array}$ & $\begin{array}{l}\text { 1. Needs } \\
\text { 2. Accuracy } \\
\text { 3. On-time }\end{array}$ & $\begin{array}{l}\text { a. Information according to } \\
\text { need } \\
\text { a. Accuracy in conveying } \\
\text { information } \\
\text { b. Suitability } \\
\text { a. Delivery on-time } \\
\text { b. Latest }\end{array}$ & Likert \\
\hline
\end{tabular}

The population is the whole of the object or subject of the study. The population in this study was students majoring in electronics engineering at the Informatics Engineering Education study program totaling 100 people.

$$
n=\frac{N}{1+N e^{2}}
$$

The sample is part of the population. The sampling technique in this study was carried out by a simple random method using the Slovins formula with a significance level of $10 \%$ obtained from a sample of 50 people.

The data were processed using the SPSS version 20 application. The instrument was tested to see its validity and reliability before being used. Then proceed with the analysis requirements test in the form of normality, reliability, and multicollinearity tests. Furthermore, hypothesis testing is carried out which consists of:

H1.There is a significant influence between the quality of information on student satisfaction

H2.There is a significant influence between quality service to student satisfaction

H3.There is a significant influence between the quality of information and service quality together on student satisfaction

\section{RESULTS AND DISCUSSIONS}

Before testing the hypothesis, the analysis requirements were first carried out consisting of tests for normality, linearity, and multicollinearity. The results of the Kolmogorov-Smirnov normality test obtained a sig value of $0.953>0.05$, which means that the data is normally distributed. The linearity test based on deviation from linearity obtained a sig value for information quality of $0.111>0.05$ and a sig value for service quality of $0.973>0.05$, which means that there is a linear relationship between the information quality variable and student satisfaction and the service quality variable and student satisfaction. Furthermore, the 
891 Information and Service Challenges in the 5.0 Industrial Revolution on Student Satisfaction: Empirical Analysis in the Department of Electronics - Muhammad Husin, Ambiyar, Nurhasan Syah

DOI: https://doi.org/10.31004/edukatif.v4i1.1956

multicollinearity test obtained a VIF value of $2.360<10$. This means that there is no multicollinearity between the variables of information quality and service quality.

Table 2

R Correlation Value

\begin{tabular}{lccccc}
\hline \multicolumn{1}{c}{$\begin{array}{c}\text { Relationship between } \\
\text { variables }\end{array}$} & R & R Square & $\begin{array}{c}\text { Adjusted R } \\
\text { Square }\end{array}$ & $\begin{array}{c}\text { Std. Error of } \\
\text { the Estimate }\end{array}$ & Sig \\
\hline $\begin{array}{l}\text { Information Quality } \rightarrow \text { Student } \\
\text { Satisfaction }\end{array}$ & 0.750 & 0.563 & 0.554 & 3.81145 & 0.000 \\
$\begin{array}{l}\text { Service Quality } \rightarrow \text { Student } \\
\text { Satisfaction }\end{array}$ & 0.650 & 0.422 & 0.410 & 4.38123 & 0.000 \\
$\begin{array}{l}\text { Quality of information and } \\
\text { quality of service together } \rightarrow\end{array}$ & 0.760 & 0.578 & 0.560 & 3.78410 & 0.000 \\
Student satisfaction
\end{tabular}

Table 3

Regression

\begin{tabular}{|c|c|c|c|c|}
\hline \multicolumn{2}{|l|}{ Variables } & Constant & B & Sig \\
\hline Information Quality & & 31.672 & 0.603 & 0.000 \\
\hline Service quality & Student & 31.625 & 0.606 & 0.000 \\
\hline $\begin{array}{l}\text { Quality of information and } \\
\text { quality of service together }\end{array}$ & $\rightarrow$ Satisfaction & 26.945 & $\begin{array}{l}0.488 \\
0.177\end{array}$ & 0.010 \\
\hline
\end{tabular}

Hypothesis 1: Information quality affects student satisfaction. As seen from Table 2, the sig value of $0.000<0.05$ means that there is a significant correlation between the quality of information and student satisfaction. The value of the coefficient of determination ( $\mathrm{R}$ Square) is 0.563 or $56.3 \%$, this number means that the quality of information contributes $56.3 \%$ influence on student satisfaction while the rest $(100 \%$ $56.3 \%=43.7 \%$ ) is influenced by other variables.

From Table 3, the sig value of $0.000<0.05$ means that the hypothesis is accepted and there is a significant influence between the quality of information on student satisfaction. The regression equation from Table 2 is obtained $\mathrm{Y}=31.672+0.603 \mathrm{X}_{1}$, meaning that the constant 31.672 states that if there is no increase in the value of information quality $\left(\mathrm{X}_{1}\right)$ then the value of student satisfaction $(\mathrm{Y})$ is a constant 31.672. And the regression coefficient of 0.603 states that for every $1 \%$ increase in the information quality variable $\left(\mathrm{X}_{1}\right)$, the value of student satisfaction will increase by 0.603 .

The existence of good and good quality information will have a good impact on student satisfaction. Accurate quality of information (P. Wang \& Li, 2020) following the development of the industrial revolution 5.0, the impact will be very large on student satisfaction (Utomo \& Darma, 2020). In conclusion, the quality of information has a positive and significant effect on student satisfaction.

Hypothesis 2: Service quality affects student satisfaction. As seen from Table 2, the sig value of 0.000 $<0.05$ means that there is a significant correlation between service quality and student satisfaction. The value of the coefficient of determination ( $\mathrm{R}$ Square) is 0.422 or $42.2 \%$, this figure means that service quality contributes $42.2 \%$ to student satisfaction while the rest $(100 \%-42.2 \%=57.8 \%)$ is influenced by other variables.

From Table 3, the sig value of $0.000<0.05$ means that the hypothesis is accepted and there is a significant influence between service quality and student satisfaction. The regression equation from Table 2 is obtained $\mathrm{Y}=31.625+0.606 \mathrm{X}_{2}$, meaning that the constant 31.625 states that if there is no increase in the value of service quality $\left(\mathrm{X}_{2}\right)$ then the value of student satisfaction $(\mathrm{Y})$ is a constant 31.625. And the regression coefficient of 0.606 states that for every $1 \%$ increase in the service quality variable $\left(\mathrm{X}_{2}\right)$, the value of student satisfaction will increase by 0.606 . 
892 Information and Service Challenges in the 5.0 Industrial Revolution on Student Satisfaction: Empirical Analysis in the Department of Electronics - Muhammad Husin, Ambiyar, Nurhasan Syah

DOI: https://doi.org/10.31004/edukatif.v4i1.1956

Service quality is the most important part of the business world (Ali et al., 2021). In addition, in education, service quality also affects student satisfaction (Khalifa et al., 2021). Fast and precise service quality (Jomnonkwao et al., 2020) can provide a sense of satisfaction and high trust in educational institutions. In conclusion, service quality has a positive and significant effect on student satisfaction.

Hypothesis 3: Quality of information and quality of service together affect student satisfaction. As seen from Table 2, the sig value of $0.000<0.05$ means that there is a significant correlation between information quality and service quality together with student satisfaction. The value of the coefficient of determination ( $R$ Square) is 0.578 or $57.8 \%$, this figure means that the quality of information and the quality of service together contribute $57.8 \%$ of the influence on student satisfaction while the rest $(100 \%-57.8 \%=42.2 \%)$ is influenced by other variables.

From Table 3, the sig value of $0.01<0.05$ means that the hypothesis is accepted and there is a significant influence between the quality of information and the quality of service together on student satisfaction. The regression equation from Table 2 is obtained $\mathrm{Y}=26.945+0.488 \mathrm{X}_{1}+0.177 \mathrm{X}_{2}$, meaning that the constant 26.945 states that if there is no increase in the value of information quality $\left(\mathrm{X}_{1}\right)$ and service quality $\left(\mathrm{X}_{2}\right)$, the value of student satisfaction $(\mathrm{Y})$ is constant 26.945. The regression coefficient $\mathrm{X}_{1}$ is 0.488 which states that for every $1 \%$ increase in the information quality variable $\left(\mathrm{X}_{1}\right)$, the student satisfaction value will increase by 0.488 with the assumption that the service quality variable is constant or not increasing. The regression coefficient $\mathrm{X}_{2}$ is 0.177 states that for every $1 \%$ increase in the service quality variable $\left(\mathrm{X}_{2}\right)$, the value of student satisfaction will increase by 0.177 assuming the information quality variable is constant or not increasing.

Quality information that is right on target (Ilyas, 2021) and according to the needs of the development of the industrial revolution 5.0 will be of great benefit to students. The rapid development of information technology and accompanied by the provision of a very adequate quality of service will provide comfort (Bayanova et al., 2020) and satisfaction for students (Pratiwi et al., 2021; Virtič et al., 2021). In conclusion, the quality of information and the quality of service together have a positive and significant effect on student satisfaction.

\section{CONCLUSIONS}

Based on the results of the study, several conclusions were obtained: 1) the quality of information has a positive effect on student satisfaction. 2) Service quality has a positive effect on student satisfaction. 3) Information quality and service quality together have a positive effect on student satisfaction.

\section{REFERENCES}

Abdurrahaman, D. T., Owusu, A., \& Bakare, A. S. (2020). Evaluating Factors Affecting User Satisfaction in University Enterprise Content Management (ECM) Systems. Electronic Journal of Information Systems Evaluation, 23(1), 1-16. https://doi.org/10.34190/ejise.20.23.1.001

Adawiyah, P. R., Policy, G., In, D., Up, S., The, O., Digital, E., Support, M., Innovative, P., In, P., \& Normal, N. (2021). Government Policy Directions In Development Start Up Of The Eco Digital Motion Support Pioneers Innovative Products In New Normal Era. Jurnal Politico, 21(1), 34-52.

Akbar, I., Yang, Z., Han, F., \& Kanat, G. (2020). The influence of negative political environment on sustainable tourism: A study of Aksu-Jabagly world heritage site, Kazakhstan. Sustainability (Switzerland), 12(1), 1-18. https://doi.org/10.3390/SU12010143

Al-Okaily, A., Al-Okaily, M., Shiyyab, F., \& Masadah, W. (2020). Accounting information system effectiveness from an organizational perspective. Management Science Letters, 10(16), 3991-4000. https://doi.org/10.5267/j.msl.2020.7.010

Alam, T. (2020). IAIC Transactions on Sustainable Digital Innovation (ITSDI) Cloud Computing and its role 
893 Information and Service Challenges in the 5.0 Industrial Revolution on Student Satisfaction: Empirical Analysis in the Department of Electronics - Muhammad Husin, Ambiyar, Nurhasan Syah DOI: https://doi.org/10.31004/edukatif.v4i1.1956

in the Information Technology. Transactions on Sustainable Digital Innovation (ITSDI), 1(2), 108-115.

Ali, B. J., Saleh, P. F., Akoi, S., Abdulrahman, A. A., Muhamed, A. S., Noori, H. N., \& Anwar, G. (2021). Impact of Service Quality on the Customer Satisfaction: Case study at Online Meeting Platforms. International Journal of Engineering, Business and Management, 5(2), 65-77. https://doi.org/10.22161/ijebm.5.2.6

Alshehri, A., \& Cumming, T. M. (2020). Mobile Technologies and Knowledge Management in Higher Education Institutions: Students' and Educators' Perspectives. World Journal of Education, 10(1), 12 22. https://doi.org/10.5430/wje.v10n1p12

Anshari, M. (2020). Workforce Mapping of Fourth Industrial Revolution: Optimization to Identity. Journal of Physics: Conference Series, 1477(7), 0-9. https://doi.org/10.1088/1742-6596/1477/7/072023

Anwar, M. (2021). Analysis of vocational interests and student's perception of work-based on society 5.0 towards learning outcomes. JPPI (Jurnal Penelitian Pendidikan Indonesia), 7(1), 57-64. https://doi.org/doi.org/10.29210/02021845

Aprilisa, E. (2020). Realizing Society 5.0 to Face the Industrial Revolution 4.0 and Teacher Education Curriculum Readiness in Indonesia. Proceeding International Conference on Science and Engineering, 3(April), 543-548. https://doi.org/10.14421/icse.v3.559

Arıc1, T., \& Kitapci, H. (2021). Emerging Technologies Applied To Quality Engineering: Current Scenario and Perspectives. Proceedings on Engineering Sciences, 3(1), 81-92. https://doi.org/10.24874/pes03.01.008

Asuquo, A. I., Dan, N. O., \& Effiong, G. T. (2020). Impact of Information Technology on Accounting Line of Works. International Journal of Recent Technology and Engineering, 9(2), 297-302. https://doi.org/10.35940/ijrte.b3522.079220

Balrwein, S., \& Rahman, A. (2020). An Assessment of the Expertise Required of Workers , in the Context of Their Capacity t o Cope With Libya 's Fourth Industrial Revolution. Journal of Industrial Engineering, Scientific Journal on Research and Application of Industrial, 5(1), 1-13.

Bayanova, A. R., Sivova, I. V., Kamasheva, Y. L., Popova, O. V., Semyanov, E. V., Shagieva, R. V., \& Yusupov, I. M. (2020). Student online services consumption: Routine practices or mistrust to digital service? Contemporary Educational Technology, 11(1), 47-54. https://doi.org/10.30935/cet.641767

Bestiantono, D. S., Agustina, P. Z. R., \& Cheng, T.-H. (2020). How Students' Perspectives about Online Learning Amid the COVID-19 Pandemic? Studies in Learning and Teaching, 1(3), 133-139. https://doi.org/10.46627/silet.v1i3.46

Bhagat, R. K., Davies Wykes, M. S., Dalziel, S. B., \& Linden, P. F. (2020). Effects of ventilation on the indoor spread of COVID-19. Journal of Fluid Mechanics, 903(F1), 1-18.

https://doi.org/10.1017/jfm.2020.720

Bostan, S., Erdem, R., Öztürk, Y. E., K1lıç, T., \& Yılmaz, A. (2020). The effect of COVID-19 pandemic on the Turkish society. Electronic Journal of General Medicine, 17(6). https://doi.org/10.29333/ejgm/7944

Butler henderson, K., Crawford, J., Rudolph, J., Lalani, K., \& K.M., S. (2020). COVID-19 in Higher Education Literature Database (CHELD V1): An open access systematic literature review database with coding rules. Journal of Applied Learning \& Teaching, 3(2), 1-6.

https://doi.org/10.37074/jalt.2020.3.2.11

Cahyono, Y., Purwanto, A., Nurul Azizah, F., Wijoyo, H., Sihotang, M., \& Sugianto, A. (2020). Impact of Service Quality,University Image and Students Satisfaction Towards Studentloyalty: Evidence From Indonesian Private Universities. Journal of Critical Review, 7(19), 148-163.

Chen, T., Peng, L., Jing, B., Wu, C., Yang, J., \& Cong, G. (2020). The impact of the COVID-19 pandemic on user experience with online education platforms in China. Sustainability (Switzerland), 12(18), 1-31. https://doi.org/10.3390/SU12187329 
894 Information and Service Challenges in the 5.0 Industrial Revolution on Student Satisfaction: Empirical Analysis in the Department of Electronics - Muhammad Husin, Ambiyar, Nurhasan Syah DOI: https://doi.org/10.31004/edukatif.v4i1.1956

Crawford, J., Henderson, K. B., Rudolph, J., Malkawi, B., Glowatz, M., Burton, R., Magni, P. A., \& Lam, S. (2020). Journal of Applied Learning \& Teaching COVID-19: 20 countries' higher education intraperiod digital pedagogy responses. Journal of Applied Learning \& Teaching, 3(1), 1-20.

https://n9.cl/o7osu

Demir, A., Maroof, L., Sabbah Khan, N. U., \& Ali, B. J. (2020). The role of E-service quality in shaping online meeting platforms: a case study from higher education sector. Journal of Applied Research in Higher Education, ahead-of-p(ahead-of-print). https://doi.org/10.1108/jarhe-08-2020-0253

Dewi, R., \& Hoesada, J. (2020). The effect of government accounting standards, internal control systems, competence of human resources, and use of information technology on quality of financial statements. International Journal of Innovative Research and Advanced Studies (IJIRAS), 7(1), 4-10.

Dwivedi, Y. K., Hughes, D. L., Coombs, C., Constantiou, I., Duan, Y., Edwards, J. S., Gupta, B., Lal, B., Misra, S., Prashant, P., Raman, R., Rana, N. P., Sharma, S. K., \& Upadhyay, N. (2020). Impact of COVID-19 pandemic on information management research and practice: Transforming education, work and life. International Journal of Information Management, 55(July), 1-20. https://doi.org/10.1016/j.ijinfomgt.2020.102211

Ekaso, D., Nex, F., \& Kerle, N. (2020). Accuracy assessment of real-time kinematics (RTK) measurements on unmanned aerial vehicles (UAV) for direct geo-referencing. Geo-Spatial Information Science, 23(2), 165-181. https://doi.org/10.1080/10095020.2019.1710437

Ellitan, L. (2020). Competing in the Era of Industrial Revolution 4.0 and Society 5.0. Jurnal Maksipreneur: Manajemen, Koperasi, Dan Entrepreneurship, 10(1), 1-12. https://doi.org/10.30588/jmp.v10i1.657

Farida, I., Setiawan, R., Maryatmi, A. S., \& Juwita, N. (2020). The Implementation of E-Government in the Industrial Revolution Era 4.0 in Indonesia. International Journal of Progressive Sciences and Technologies (IJPSAT, 22(2), 340-346. http://ijpsat.ijsht-journals.org

Freeman, S., \& Eykelbosh, A. (2020). COVID - 19 and outdoor safety: Considerations for use of outdoor recreational spaces. National Collaborating Center for ENvironmental Health, April 14, 1-15.

George, A. S., \& George, A. S. H. (2020). Industrial Revolution 5.0: the Transformation of the Modern Manufacturing Process To Enable Man and Machine To Work Hand in Hand. Journal of Seybold Report, 15(9), 214-234.

Hasbullah, M. A., Selirowangi, N. B., Pradana, M. S., Khulel, B., \& Hudi, M. (2020). Quality and Affordable Education through Quality Management Systems in Higher Education. EDUTEC : Journal of Education And Technology, 3(2), 151-160. https://doi.org/10.29062/edu.v3i2.52

Hidayat, H., Tasrif, E., Jaya, P., Anwar, M., Thamrin, T., Zulwisli, Z., Hadi, A., Budayawan, K., Husin, M., \& Asmara, D. (2021). The Empirical Analysis of Industrial Work Challenges in the Industrial Revolution 5.0 Towards a Grade Point Average (GPA) for Electronic Engineering Education Students. International Journal of Online and Biomedical Engineering (IJOE), 17(09), 21-34. https://doi.org/10.3991/ijoe.v17i09.25679

Husin, M., Giatman, M., \& Usmeldi, N. J. (2021). Learning in Vocational Education During the Covid 19 Outbreak: A Systematic Review and Meta- Analysis. Advances in Social Science, Education and Humanities Research, 608 (Ictvet), 103-109.

https://doi.org/https://dx.doi.org/10.2991/assehr.k.211208.018

Ilyas, A. (2021). Pengaruh Digitalisasi Pelayanan Publik terhadap Kinerja Pegawai pada Masa Pandemi di Lembaga Pendidikan dan Pelatihan. Edukatif: Jurnal Ilmu Pendidikan, 3(6), 5231-5239. https://doi.org/https://doi.org/10.31004/edukatif.v3i6.1173

Jaya, P. E. J. (2020). Influence of the quality of human resources, communication information technology, and product mounting requirements on product performance. International Research Journal of Management, IT and Social Sciences, 7(3), 29-37. https://doi.org/10.21744/irjmis.v7n3.883 
895 Information and Service Challenges in the 5.0 Industrial Revolution on Student Satisfaction: Empirical Analysis in the Department of Electronics - Muhammad Husin, Ambiyar, Nurhasan Syah DOI: https://doi.org/10.31004/edukatif.v4i1.1956

Jomnonkwao, S., Champahom, T., \& Ratanavaraha, V. (2020). Methodologies for determining the service quality of the intercity rail service based on users' perceptions and expectations in Thailand. Sustainability (Switzerland), 12(10), 1-20. https://doi.org/10.3390/su12104259

Joseph Paschal, M., \& Mkulu, D. G. (2020). Online Classes during COVID-19 Pandemic in Higher Learning Institutions in Africa. Global Research in Higher Education, 3(3), 1-21. https://doi.org/10.22158/grhe.v3n3p1

Kandiko Howson, C., \& Lall, M. (2020). Higher education reform in Myanmar: neoliberalism versus an inclusive developmental agenda. In Globalisation, Societies and Education (Vol. 18, Issue 2). https://doi.org/10.1080/14767724.2019.1689488

Khalifa, G. S. A., Binnawas, M. S. H., Alareefi, N. A., Mohammed, S., Alsaadi, T. A., Alneadi, K. M., \& Alkhateri, A. (2021). The Role of Holistic Approach Service Quality on Student's Behavioural Intentions: The Mediating Role of Happiness and Satisfaction. City University EJournal of Academic Research (CUeJAR), 3(1), 12-32. https://www.city.edu.my/CUeJAR

Kurdi, B. Al, Alshurideh, M., \& Alnaser, A. (2020). The impact of employee satisfaction on customer satisfaction: Theoretical and empirical underpinning. Management Science Letters, 10(15), 3561-3570. https://doi.org/10.5267/j.msl.2020.6.038

Kuzieva, N. R. (2019). Free economic zones of Uzbekistan : development , operation and features of the tax regime. International Journal of Reserach in Social Sciences, 9(4), 1173-1183.

Li, F., Lu, H., Hou, M., Cui, K., \& Darbandi, M. (2021). Customer satisfaction with bank services: The role of cloud services, security, e-learning and service quality. Technology in Society, 64(July 2020), 101487. https://doi.org/10.1016/j.techsoc.2020.101487

Liu, Y., Zhang, Y., Qiao, W., Zhou, L., \& Coates, H. (2020). Ensuring the sustainability of university learning: Case study of a leading Chinese University. Sustainability (Switzerland), 12(17), 1-18. https://doi.org/10.3390/SU12176929

Locock, L., Graham, C., King, J., Parkin, S., Chisholm, A., Montgomery, C., Gibbons, E., Ainley, E., Bostock, J., Gager, M., Churchill, N., Dopson, S., Greenhalgh, T., Martin, A., Powell, J., Sizmur, S., \& Ziebland, S. (2020). Understanding how front-line staff use patient experience data for service improvement: an exploratory case study evaluation. Health Services and Delivery Research, 8(13), 1170. https://doi.org/10.3310/hsdr08130

Longo, F., Padovano, A., \& Umbrello, S. (2020). Value-oriented and ethical technology engineering in industry 5.0: A human-centric perspective for the design of the factory of the future. Applied Sciences (Switzerland), 10(12), 1-25. https://doi.org/10.3390/APP10124182

Maity, S., Sahu, T. N., \& Sen, N. (2021). Panoramic view of digital education in COVID-19: A new explored avenue. Review of Education, 9(2), 405-423. https://doi.org/10.1002/rev3.3250

Malau, M. (2021). Analysis of the Accounting Learning Digital Disruptive in Industrial Revolution 4.0 and Society 5.0. Proceedings of the 2nd Annual Conference on Blended Learning, Educational Technology and Innovation (ACBLETI 2020), 560 (Acbleti 2020), 276-281. https://doi.org/10.2991/assehr.k.210615.054

Mhlanga, D., \& Moloi, T. (2020). COVID-19 and the digital transformation of education: What are we learning on 4ir in South Africa? Education Sciences, 10(7), 1-11. https://doi.org/10.3390/educsci10070180

Minh, T. H. (2020). The Relationship Between Service Expectations and Service Quality in University Education. International Journal of Research in Engineering, Science and Management, 3(12), 68-70. https://doi.org/10.47607/ijresm.2020.409

Mulyono, H., Hadian, A., Purba, N., \& Pramono, R. (2020). Effect of Service Quality Toward Student Satisfaction and Loyalty in Higher Education. Journal of Asian Finance, Economics and Business, 
896 Information and Service Challenges in the 5.0 Industrial Revolution on Student Satisfaction: Empirical Analysis in the Department of Electronics - Muhammad Husin, Ambiyar, Nurhasan Syah DOI: https://doi.org/10.31004/edukatif.v4i1.1956

7(10), 929-938. https://doi.org/10.13106/jafeb.2020.vol7.no10.929

Oztemel, E., \& Gursev, S. (2020). Literature review of Industry 4.0 and related technologies. Journal of Intelligent Manufacturing, 31(1), 127-182. https://doi.org/10.1007/s10845-018-1433-8

Pratiwi, D. I., Astuti, S. W., Puspitasari, A., \& Fikria, A. (2021). Analisis Tata Kelola Perguruan Tinggi Vokasi dan Indeks Kepuasan Siswa pada Politeknik Perkeretaapian Indonesia Madiun. Edukatif: Jurnal Ilmu Pendidikan, 3(6), 4556-4567. https://doi.org/https://doi.org/10.31004/edukatif.v3i6.1491

Purbasari, R., Sari, D. S., \& Muttaqin, Z. (2020). Mapping of Digital Industry Competitive Advantages: Market-Based View Approach. Buscompress.Com, 9(4), 380-398.

Rachmadtullah, R., Yustitia, V., Setiawan, B., Fanny, A. M., Pramulia, P., Susiloningsih, W., Rosidah, C. T., Prastyo, D., \& Ardhian, T. (2020). The challenge of elementary school teachers to encounter superior generation in the 4.0 industrial revolution: Study literature. International Journal of Scientific and Technology Research, 9(4), 1879-1882.

Restuputri, D. P., Masudin, I., \& Sari, C. P. (2020). Customers perception on logistics service quality using Kansei engineering: empirical evidence from indonesian logistics providers. Cogent Business and Management, 7(1), 1-26. https://doi.org/10.1080/23311975.2020.1751021

Rindfleisch, A. (2020). The Second Digital Revolution. Marketing Letters, 31(1), 13-17. https://doi.org/10.1007/s11002-019-09509-4

Rosa, A. T. R., \& Mujiarto. (2020). Teacher development potential (Creativity and innovation) education management in engineering training, coaching and writing works through scientific knowledge intensive knowledge based on web research in the industrial revolution and society. International Journal of Higher Education, 9(4), 161-168. https://doi.org/10.5430/ijhe.v9n4p161

Rymarczyk, J. (2021). The Impact of Industrial Revolution ( Industry 4 . 0 ) on Naval Industry in. 9(1), 105117. https://doi.org/10.15678/EBER.2021.090107

samimi, A. (2020). Risk Management in Information Technology. Progress in Chemical and Biochemical Research, 3(2), 130-134. https://doi.org/10.33945/sami/pcbr.2020.2.6

Saravanakumar, R. (2020). Indian Higher Education : Journal of Critical Reviews, 7(2), 542-545. https://doi.org/http://dx.doi.org/10.31838/jcr.07.02.101

Shaddiq, S., Haryono, S., Muafi, M., \& Isfianadewi, D. (2021). Antecedents and Consequences of Cyberloafing in Service Provider Industries: Industrial Revolution 4.0 and Society 5.0. Journal of Asian Finance, Economics and Business, 8(1), 157-167. https://doi.org/10.13106/jafeb.2021.vol8.no1.157

Shukla, T., Dosaya, D., Nirban, V. S., \& Vavilala, M. P. (2020). Factors extraction of effective teachinglearning in online and conventional classrooms. International Journal of Information and Education Technology, 10(6), 422-427. https://doi.org/10.18178/ijiet.2020.10.6.1401

Shukshina, L. V, Nizamutdinova, S. M., Mamedov, A. A., Kidinov, A. V, Litvinov, A. V, \& Lvova, E. N. (2020). Specific Features of Organizational And Methodological Support for The Development of Mediation Services In Educational Institutions ( Domestic Experience). Systematic Reviews in Pharmacy, 11(12), 1787-1792.

Silalahi, T. F., \& Hutauruk, A. F. (2020). The Application of Cooperative Learning Model during Online Learning in the Pandemic Period. Budapest International Research and Critics Institute-Journal, 3(3), $1683-1691$.

Sofyani, H., Riyadh, H. A., \& Fahlevi, H. (2020). Improving service quality, accountability and transparency of local government: The intervening role of information technology governance. Cogent Business and Management, 7(1), 1-21. https://doi.org/10.1080/23311975.2020.1735690

Suan CHIN, S. T. (2021). Influence of Emotional Intelligence on the Workforce for Industry 5.0. Journal of Human Resources Management Research, 2021, 1-7. https://doi.org/10.5171/2021.882278 
897 Information and Service Challenges in the 5.0 Industrial Revolution on Student Satisfaction: Empirical Analysis in the Department of Electronics - Muhammad Husin, Ambiyar, Nurhasan Syah

DOI: https://doi.org/10.31004/edukatif.v4i1.1956

Suresh, B., Rama, B., \& Ahmed, H. (2004). Information technology for rural development: An overview. The Economic Challenger, 6(23), 34-37.

Taat, M. S., \& Francis, A. (2020). Factors Influencing th e Students' Acceptance of E-Learning at Teacher Education Institute: An Exploratory Study in Malaysia. International Journal of Higher Education, 9(1), 133-141. https://doi.org/10.5430/ijhe.v9n1p133

Tešić, D. (2020). Measuring dimensions of service quality. Strategic Management, 25(1), 12-20. https://doi.org/10.5937/straman2001012t

Toquero, C. M. (2020). Challenges and Opportunities for Higher Education amid the COVID-19 Pandemic: The Philippine Context. Pedagogical Research, 5(4), 1-5. https://doi.org/10.29333/pr/7947

Utomo, I. G. W., \& Darma, G. S. (2020). Measuring optimization of digital military programs: an innovation of information and communication systems in industrial digitalization 4.0. International Research Journal of Engineering, IT \& Scientific Research, 6(2), 39-46. https://doi.org/10.21744/irjeis.v6n2.862

Virtič, M. P., Dolenc, K., \& Šorgo, A. (2021). Changes in online distance learning behaviour of university students during the coronavirus disease 2019 outbreak, and development of the model of forced distance online learning preferences. European Journal of Educational Research, 10(1), 393-411. https://doi.org/10.12973/EU-JER.10.1.393

Wang, P., \& Li, X. (2020). Assessing the quality of information on wikipedia: A deep-learning approach. Journal of the Association for Information Science and Technology, 71(1), 16-28. https://doi.org/10.1002/asi.24210

Wang, Y. (2021). Correlational research on facial and clinical characteristics of adolescents with obsessivecompulsive disorder. Research Square, March 26th, 1-17. https://doi.org/https://doi.org/10.21203/rs.3.rs-362348/v1 License:

Yosintha, R. (2020). Indonesian Students' Attitudes towards EFL Learning in Response to Industry 5.0. Metathesis: Journal of English Language, Literature, and Teaching, 4(2), 163. https://doi.org/10.31002/metathesis.v4i2.2360 